\title{
Financiële prikkels en geprefereerde pensioenleeftijd
}

Citation for published version (APA):

Kerkhofs, M., Fouarge, D., \& Ester, P. (2009). Financiële prikkels en geprefereerde pensioenleeftijd. Tijdschrift voor Arbeidsvraagstukken, 25(1), 20-37.

Document status and date:

Published: 01/01/2009

Document Version:

Publisher's PDF, also known as Version of record

\section{Please check the document version of this publication:}

- A submitted manuscript is the version of the article upon submission and before peer-review. There can be important differences between the submitted version and the official published version of record.

People interested in the research are advised to contact the author for the final version of the publication, or visit the DOI to the publisher's website.

- The final author version and the galley proof are versions of the publication after peer review.

- The final published version features the final layout of the paper including the volume, issue and page numbers.

Link to publication

\footnotetext{
General rights rights.

- You may freely distribute the URL identifying the publication in the public portal. please follow below link for the End User Agreement:

www.umlib.nl/taverne-license

Take down policy

If you believe that this document breaches copyright please contact us at:

repository@maastrichtuniversity.nl

providing details and we will investigate your claim.
}

Copyright and moral rights for the publications made accessible in the public portal are retained by the authors and/or other copyright owners and it is a condition of accessing publications that users recognise and abide by the legal requirements associated with these

- Users may download and print one copy of any publication from the public portal for the purpose of private study or research.

- You may not further distribute the material or use it for any profit-making activity or commercial gain

If the publication is distributed under the terms of Article $25 \mathrm{fa}$ of the Dutch Copyright Act, indicated by the "Taverne" license above, 


\title{
Financiële prikkels en geprefereerde pensioenleeftijd
}

\author{
Marcel Kerkhofs, Didier Fouarge en Peter Ester*
}

\begin{abstract}
Door de veranderende leeftijdsopbouw van de Nederlandse beroepsbevolking wordt het steeds belangrijker dat mensen tot op hogere leeftijd op de arbeidsmarkt actief blijven. Dit kan worden gestimuleerd door de financiële vormgeving van de pensioenregelingen aan te passen. Twee uit de economische theorie bekende mechanismen spelen daarbij een rol. Allereerst is dat het inkomenseffect dat optreedt bij een algehele verlaging van pensioenen. Het tweede mechanisme is het substitutie-effect dat ontstaat als in een pensioenregeling de keuze voor langer doorwerken financieel aantrekkelijker wordt gemaakt en de keuze voor vroeg uittreden financieel minder aantrekkelijk. Aanpassingen van pensioenregelingen omvatten in het algemeen een combinatie van beide mechanismen. Door middel van een vignettenonderzoek wordt in dit artikel nagegaan hoe gevoelig werknemers bij de keuze van hun pensioenleeftijd zijn voor dergelijke financiële prikkels. Voor dit doel is aan deelnemers van het CentERpanel een aantal realistische keuzemogelijkheden voorgelegd, waarin prikkels tot doorwerken zijn ingebouwd door middel van wisselende combinaties van substitutie- en inkomenseffect. Als het gaat om directe pensionering, blijken werknemers gevoelig voor beide vormen van financiële prikkels, maar het meest voor het substitutie-effect. Bij gefaseerd uittreden, waarbij de omvang van de werkweek stapsgewijs wordt teruggebracht, is het verschil tussen beide vormen van prikkels klein.
\end{abstract}

Trefwoorden: vervroegde uittreding, gefaseerde uittreding, pensioenleeftijd, vignettenmethode

\section{Inleiding}

Het CBS voorspelt dat in 2040 bijna een kwart van de Nederlandse bevolking 65 jaar of ouder is. Dat is bijna een verdubbeling van het aantal ouderen ten opzichte van de huidige situatie. Zoals analyses van het Centraal Planbureau duidelijk maken, zijn bij dergelijke demografische ontwikkelingen aanpassingen van regelingen rond uittreding en sociale zekerheid nodig om de betaalbaarheid van het stelsel van sociale voorzieningen en uitgaven voor de zorg veilig te stellen (Ewijk et al., 2006). In de afgelopen jaren is hiermee al een begin gemaakt, deels in de vorm van overheidsbeleid, deels door nieuwe afspraken tussen sociale partners. Verdere ingrepen lijken echter onvermijdelijk. De aard en omvang van deze ingrepen zijn inmiddels inzet van politiek debat. ${ }^{1}$ Op één punt lijken allen het eens: om de verhouding tussen de aantallen actieven en inactieven niet te scheef te laten worden, moet de arbeidsdeelname omhoog. Nederlanders zullen tot op hogere leeftijd op de arbeidsmarkt actief moeten blijven dan in de afgelopen decennia gebruikelijk was. Om dit te bereiken zal langer doorwerken financieel aantrekkelijker moeten worden of vroegtijdig stoppen minder aantrekkelijk.

In dit artikel staat daarom de vraag centraal welke rol financiële prikkels spelen in de keuzes rond vervroegd uittreden in Nederland. Door middel van een experimenteel-

* Marcel Kerkhofs is werkzaam bij OSA Institute for Labour Studies, Universiteit van Tilburg, Postbus 90153, 5000 LE Tilburg. E-mail: m.j.m.kerkhofs@uvt.nl.

Didier Fouarge is verbonden aan het Researchcentrum voor Onderwijs en Arbeidsmarkt (ROA), Universiteit Maastricht.

Peter Ester is werkzaam bij OSA Institute for Labour Studies, Universiteit van Tilburg. 
economische onderzoeksopzet - waarin werknemers gevraagd wordt een keuze te maken uit een reeks uittredeleeftijden met bijbehorende pensioeninkomens - wordt onderzocht in welke mate werknemers geprikkeld kunnen worden tot langer doorwerken. Het vernieuwende element van dit onderzoek is dat de experimentele opzet het mogelijk maakt om het belang van substitutie- (belonen van langer werken en straffen van korter werken) en inkomenseffecten (langer doorwerken om dezelfde pensioenrechten te krijgen) bij uittreding te bepalen. De mogelijkheid van geleidelijke uittreding door stapsgewijze vermindering van het aantal gewerkte uren, wordt daarbij expliciet in de beschouwing betrokken. Omdat de keuze om al dan niet door te werken niet alleen afhankelijk is van financiële prikkels (zie bijvoorbeeld de recente bijdrage van Jettinghoff en Smulders (2008) in dit tijdschrift) wordt in de analyses rekening gehouden met sociaaleconomische factoren en persoonskenmerken die mede bepalen op welke leeftijd het arbeidsproces wordt verlaten.

Het artikel is als volgt opgebouwd. Allereerst wordt nader ingegaan op de beleidsachtergrond en bestaand onderzoek. Vervolgens wordt het experimenteel design toegelicht en de relatie tot de economische theorie rond substitutie- en inkomenseffecten. De analyse van de keuzes van de respondenten in het experiment wordt daarna besproken. Wij sluiten af met de voornaamste conclusies en enkele beleidsimplicaties.

\section{Pensionering en financiële prikkels: beleid en onderzoek}

\section{Van VUT naar prepensioen}

In de loop van de jaren negentig van de vorige eeuw zijn bestaande VUT-regelingen versoberd dan wel afgeschaft in een groot aantal sectoren en bedrijven. Ontstaan in de jaren zeventig en tachtig om op de arbeidsmarkt plaats te maken voor jongeren, vormden zij voor oudere werknemers een offer you can't refuse. Vutters maakten doorgaans gebruik van de VUT op het eerste moment dat dit mogelijk was en de VUT-leeftijd lag in het algemeen tussen de 58 en 62 jaar (Nelissen, 2001). VUT-regelingen werkten met een omslagstelsel, waarbij de uitkeringen werden gefinancierd uit premies betaald door de nog actieve werknemers en door werkgevers. Hierdoor zouden deze regelingen op langere termijn onbetaalbaar worden, nog los van het verlies aan menselijk kapitaal door economisch gezien onnodig vroege uittreding. Door deze regelingen werd langer doorwerken bestraft met een hoge impliciete belastingvoet (Lindeboom, 1999; Kapteyn \& De Vos, 1999). Langer doorwerken leverde daardoor weinig op of kostte vaak zelfs geld. De oorzaak van deze 'uittredingsval' lag in de systematiek achter de meeste VUTregelingen, waarin VUT-rechten vervielen als de werknemer daar geen gebruik van maakte en de pensioenopbouw tijdens de VUT-periode net zo hard doorliep als wanneer iemand van de VUT-regeling afzag. Bij de ombouw van VUT-naar prepensioenregelingen aan het einde van de vorige eeuw zijn deze voor langer doorwerken nadelige elementen herzien. In het algemeen zijn prepensioenuitkeringen lager dan VUT-uitkeringen (Soede en Bijkerk, 2003, p. 25-26) en zijn in de huidige prepensioenregelingen meer elementen van een individuele pensioenspaarregeling ingebouwd. Vervroegd uittreden is daardoor financieel minder aantrekkelijk geworden.

De keuze van de leeftijd waarop iemand definitief stopt met werken, wordt in de relevante economische theorie primair bezien vanuit de afweging tussen de waarde van vrije tijd en het nut dat wordt ontleend aan consumptie of inkomen (Lazear, 1986; 
Hurd, 1990). Door te blijven werken genereert men extra inkomen en blijft men bijdragen aan de pensioenopbouw. Daar staat tegenover dat daarvoor een zekere hoeveelheid vrije tijd wordt opgegeven. Hoewel uittreden met meer te maken heeft dan met geld alleen, ${ }^{2}$ ligt in het overgrote deel van de studies de nadruk op het effect van financiële prikkels op het uittredingsgedrag.

Het belang van financiële prikkels is in de literatuur veelvuldig besproken en onderzocht op basis van revealed preferences, dat wil zeggen op basis van in het verleden waargenomen uittredingsbeslissingen. Zo laat een recente internationaalvergelijkende studie door Schils (2005) zien dat in landen met genereuze arrangementen voor vervroegde uittreding of met gemakkelijk toegankelijke alternatieve uittredingsroutes - zoals de werkloosheids- of arbeidsongeschiktheidsregelingen - men minder lang doorwerkt. De vraag is of de versobering van vervroegde uittredingsmogelijkheden geleid heeft tot een verschuiving in de pensioenleeftijd. Uit onderzoek van Huynen en Fouarge (2005), op basis van administratieve data van het CBS voor de periode 1995-2000, blijkt dat de geleidelijke omzetting van VUT- naar prepensioenregelingen gepaard is gegaan met een stijging van de gemiddelde pensioenleeftijd van 60,5 jaar in 1996 naar 61,1 jaar aan het eind van 1999. Euwals et al. (2005) laten zien dat oudere werknemers aan het eind van de vorige eeuw gemiddeld vier maanden langer zijn gaan doorwerken als gevolg van de geleidelijke overgang van de bestaande VUT-regeling naar een nieuwe prepensioenregeling. Zonder overgangsmaatregelen zou dit effect naar schatting negen maanden zijn geweest. Echter, bestaand onderzoek maakt het niet goed mogelijk om te concluderen of werkenden beter te prikkelen zijn tot langer doorwerken door de prijs van vroege uittreding hoger te maken (substitutie-effect) of door pensioenen te verlagen (inkomenseffect). Het hier besproken experiment biedt een antwoord.

\section{Stated preferences en revealed preferences}

In de uitgebreide literatuur over uittredingsbeslissingen ligt de nadruk sterk op de analyse van feitelijk waargenomen keuzes van mensen in het (recente) verleden. Bij dergelijke revealed preferences, voorkeuren geopenbaard door middel van feitelijk gemaakte keuzes, zijn de omstandigheden waaronder de keuze is gemaakt zeer heterogeen en is de informatie daarover vaak beperkt. Bij de overgang van VUT naar prepensioenregelingen is bijvoorbeeld rijkelijk gebruik gemaakt van overgangsregelingen. Het is daarom opvallend dat voor dit soort onderzoek nog weinig gebruik is gemaakt van de stated-preference-benadering, ook wel aangeduid als de vignettenmethode, waarbij informatie over individuele voorkeuren verkregen wordt door mensen te vragen wat zij in een bepaald nauw omschreven keuzeprobleem zouden kiezen, of de geboden keuzemogelijkheden te beoordelen. Deze methode maakt het mogelijk om preciezer te controleren voor de omstandigheden waaronder mensen hun beslissing moeten nemen. Daarbij is het met deze aanpak ook mogelijk informatie te verkrijgen over de beslissing van mensen die de feitelijke keuze pas in de toekomst gaan maken. Dit biedt belangrijke meerwaarde, aangezien het aannemelijk is dat de 'ouderen van de toekomst' in een aantal voor de uittredingsbeslissing belangrijke opzichten anders zullen zijn dan de mensen uit eerdere generaties die deze fase in hun arbeidsloopbaan inmiddels zijn gepasseerd. Daar staat als mogelijk nadeel tegenover dat mensen, als zij eenmaal voor de feitelijke keuze staan, een andere afweging kunnen maken dan zij jaren eerder - en aanmerkelijk vrijblijvender - binnen een vignettenonderzoek hebben gedaan. De ervaringen met dit soort onderzoek onderstrepen het belang van transparante en voor de 
deelnemers goed voorstelbare keuzeproblemen (vignetten) voor de validiteit van de uitkomsten. Op die manier kan deze methode een waardevolle bijdrage leveren aan ons inzicht in de manier waarop mensen hun keuzes maken en welke factoren daarop van invloed zijn. Zie Louvière et al. (2000) en Carson et al. (1996) voor een onderbouwing van de externe validiteit van de vignettenmethode.

\section{Eerder experimenteel onderzoek naar uittreding}

Hoewel er tot voor kort weinig gebruik is gemaakt van de vignettenmethode bij het onderzoeken van de effecten van financiële prikkels, lijkt daar in de afgelopen jaren, in ieder geval in Nederland, verandering in te komen. Zo hebben Van Dalen en Henkens (2000) gebruik gemaakt van een vraag over de gewenste uittredeleeftijd indien men gebruik zou kunnen maken van een fictieve prepensioenregeling waarbij de vervangingsratio varieert afhankelijk van de gekozen uittredeleeftijd. $\mathrm{Zij}$ voorspellen dat prepensioenregelingen het werkzame leven met één tot twee jaar zullen verlengen. Voornamelijk mannen blijken gevoelig voor de inkomensgevolgen van vervroegd uittreden en zullen daarom langer doorwerken.

Nelissen (2001) heeft de vignettenmethode gebruikt om het effect van prepensioen en flexibel pensioen op de uittredeleeftijd te bepalen. In dit onderzoek wordt een groot aantal verschillende experimenten tegelijk ingezet. Gegeven bepaalde uitkeringspercentages bij uittreding moet bijvoorbeeld aangegeven worden bij welke leeftijd men zou willen uittreden. Daarnaast wordt ook direct aan respondenten gevraagd of men gebruik zou maken van de mogelijkheid om op een gegeven leeftijd met een gegeven pensioenuitkering uit het arbeidsproces terug te treden. Op grond van de informatie die dit oplevert, leidt Nelissen af dat de overstap naar prepensioenregelingen op een termijn van tien jaar zou leiden tot een 5 procentpunt hogere arbeidsparticipatie dan bij de toenmalige VUT-regelingen. Bij flexibele pensioenregelingen zou het effect op de participatie 8 procentpunt bedragen.

Van Soest et al. (2006) hebben in een enquête in 2004 aan respondenten gevraagd verschillende fictieve uittredingsmogelijkheden, waarbij pensioenleeftijd en vervangingsratio's gevarieerd werden, te waarderen in termen van rapportcijfers. De belangrijkste conclusie van hun analyse is dat er geen sterke voorkeur is voor deeltijduittreding en dat sterke financiële prikkels noodzakelijk zijn om mensen te bewegen tot op hogere leeftijd door te werken. Begin 2005 hebben Bruinshoofd en Grob (2006) de respondenten in het DNB Huishoudenssurvey (DHS) een aantal verschillende pensioenschema's voorgelegd met de vraag voor elk daarvan aan te geven op welke leeftijd zij zouden stoppen met werken. De conclusie van dit onderzoek is dat het ophogen van de pensioenleeftijd met één jaar ertoe zal leiden dat mensen gemiddeld vijf à zes maanden langer zullen doorwerken.

\section{Onderzoeksopzet en relatie tot theorie}

\section{Data: beschrijving van het experiment}

De enquête voor dit onderzoek is in juni 2005 gehouden onder deelnemers aan het CentERpanel. Dit internetpanel vormt een representatieve steekproef uit de Neder- 
landse bevolking en omvat ruim 2000 huishoudens. ${ }^{3}$ Kern van de enquête is een vignettenexperiment, waarin respondenten een pensioenschema krijgen voorgelegd met keuzemogelijkheden om op verschillende leeftijden uit te treden, met daaraan gekoppeld de vraag aan welke van de mogelijkheden zij de voorkeur zouden geven. In verband met de betrouwbaarheid van de aanpak is het experiment enkel voorgelegd aan respondenten voor wie het keuzeprobleem relevant is, of relevant is geweest, namelijk mensen van 25 tot en met 75 jaar oud die momenteel betaald werk hebben of dat hadden in de voor de vraagstelling van belang zijnde leeftijdsfase (55 tot 60 jaar). In totaal hebben 1221 respondenten de vragenlijst volledig ingevuld, waarvan 975 werkenden jonger dan 60, 232 respondenten van 60 jaar of ouder die tussen hun 55ste en 60ste levensjaar nog betaald werk hadden verricht en 14 respondenten jonger dan 60 die op het moment van de enquête geen werk hadden, maar na hun 55 ste verjaardag nog wel betaald werk hadden verricht. Tabel 1 geeft een overzicht van het aantal respondenten, uitgesplitst naar geslacht, leeftijd en opleiding.

Tabel I Aantal respondenten in het vignettenonderzoek onder deelnemers aan het CentERpanel

\begin{tabular}{|c|c|c|c|c|c|c|}
\hline & \multicolumn{2}{|c|}{ Alle respondenten } & \multicolumn{2}{|c|}{$\begin{array}{c}\text { Leeftijd } 25-59 \text { jaar \& } \\
\text { werkend ten tijde van } \\
\text { enquête }\end{array}$} & \multicolumn{2}{|c|}{$\begin{array}{l}\text { Leeftijd } \geq 60 \text { jaar } \& \\
\text { gewerkt na } 55 \text { ste en } \\
\text { voor } 60 \text { ste levensjaar }\end{array}$} \\
\hline & Aantal & $\%$ & Aantal & $\%$ & Aantal & $\%$ \\
\hline Allen & 1.221 & & 975 & & 246 & \\
\hline \multicolumn{7}{|l|}{ Geslacht } \\
\hline $\operatorname{man}$ & 739 & 60,5 & 553 & 56,7 & 186 & 75,6 \\
\hline vrouw & 482 & 39,5 & 422 & 43,3 & 60 & 24,4 \\
\hline \multicolumn{7}{|l|}{ Leeftijd } \\
\hline jonger dan 40 & 380 & $3 I, I$ & 380 & 39,0 & & \\
\hline $40 \mathrm{t} / \mathrm{m} 54$ & 467 & 38,2 & 467 & 47,9 & & \\
\hline $55 \mathrm{t} / \mathrm{m} 64$ & 215 & 17,6 & 128 & 13,1 & 87 & 35,4 \\
\hline 65 jaar en ouder & 159 & 13,0 & & & 159 & 64,6 \\
\hline \multicolumn{7}{|l|}{ Hoogst voltooide opleiding } \\
\hline basisonderwijs of vmbo & 334 & 27,4 & 246 & 25,2 & 88 & 35,8 \\
\hline havo, vwo of mbo & 400 & 32,8 & 333 & 34,2 & 67 & 27,2 \\
\hline hbo of wo & 487 & 39,9 & 396 & 40,6 & 91 & 37,0 \\
\hline
\end{tabular}

Het voorgelegde keuzemenu heeft veel weg van een regulier pensioenoverzicht. Elke keuzemogelijkheid betreft een leeftijd waarop de respondent volledig kan stoppen met werken en de bijbehorende pensioenuitkering die de respondent vanaf dat moment netto zal ontvangen. Deze pensioenrechten zijn uitgedrukt als percentage van het netto inkomen in de laatste baan, het zogenaamde netto-netto vervangingspercentage (replacement rate). Verondersteld wordt dat respondenten deze pensioenrechten voor de rest van hun leven houden en dat hun AOW uitkering hierin is verwerkt. Impliciet is daarbij uitgegaan van een volledige pensioenopbouw om de experimentele opzet zo transparant mogelijk te houden. Bij het vaststellen van de vervangingspercentages is het volgende basisscenario als uitgangspunt genomen: mensen die op hun 66ste jaar stoppen met werken, gaan er nadien netto niet op achteruit (netto-netto vervangingspercentage is $100 \%) .{ }^{4}$ Elk jaar dat zij eerder stoppen met werken, maakt het vervangingspercentage 5 procentpunt lager, en elk jaar dat zij langer doorwerken maakt het 5 procentpunt hoger. Van dit basisscenario zijn twee varianten gebruikt: één waarin alle rechten pas een jaar later ingaan en één waarin het vervangingspercentage met 7 in plaats van 5 procentpunten toeneemt voor elk jaar dat langer wordt doorgewerkt. 
Van de drie resulterende pensioenregimes krijgt elke respondent er door loting één toegewezen.

Voor werkenden jonger dan 60 luidde het keuzeprobleem als volgt:

In de volgende vragen leggen we u een stelsel voor flexibele pensionering voor. Binnen dit stelsel kunt u op verschillende leeftijden stoppen met werken, maar hoe eerder u stopt, hoe lager uw pensioen zal zijn.

In het overzicht staat bij elke leeftijd waarop u kunt stoppen hoeveel pensioen $u$ dan vanaf die leeftijd ontvangt. De hoogte van het pensioen is netto (d.w.z. vrij besteedbaar, na aftrek van belasting en premies) en wordt gegeven als percentage van uw netto loon. Uw AOW is hier al in meegeteld.

Bijvoorbeeld: als u stopt op leeftijd 61, ontvangt u vanaf dat moment netto $75 \%$ van uw netto loon als pensioen.

Op welke leeftijd zou u stoppen met werken, als u uit deze mogelijkheden mag kiezen?

Bij deze vragen werd vervolgens een tabel getoond met de eerste en - afhankelijk van het toegewezen regime - één van de andere drie kolommen uit tabel 2. Aan de overige respondenten zijn dezelfde vragen gesteld, maar dan met het verzoek die te beantwoorden vanuit de situatie van hun laatste baan voor hun zestigste verjaardag.

Tabel 2 Netto-netto vervangingspercentages ${ }^{\mathrm{a}}$ in keuze-experiment

\begin{tabular}{lccc}
\hline & \multicolumn{3}{c}{ Regime (willekeurig toegewezen) } \\
Uittredeleeftijd & I & II & III \\
& I00\% bij $\mathbf{6 6}$ jaar & I00\% bij $\mathbf{6 6}$ jaar & 100\% bij $\mathbf{6 7}$ jaar \\
stapgrootte: 5\% & stapgrootte: 7\% & stapgrootte: 5\% \\
\hline 59 & 65 & 51 & 60 \\
60 & 70 & 58 & 65 \\
61 & 75 & 65 & 70 \\
62 & 80 & 72 & 75 \\
63 & 85 & 79 & 80 \\
64 & 90 & 86 & 85 \\
65 & 95 & 93 & 90 \\
66 & 100 & 100 & 95 \\
67 & 105 & 107 & 100 \\
68 & 110 & 114 & 105 \\
\hline
\end{tabular}

\footnotetext{
${ }^{a}$ Het netto-netto vervangingspercentage geeft aan hoeveel het netto inkomen na pensionering bedraagt als percentage van het netto inkomen voor pensionering.
}

Regime I is het genoemde basisscenario, de beide andere regimes vormen daarop een versobering. Bij regime II is de afname van de pensioenrechten bij eerdere uittreding sterker, namelijk 7 in plaats van 5 procentpunten voor elk jaar dat eerder wordt gestopt met werken. Regime III verschilt van regime I in de zin dat bij elke uittredeleeftijd de vervangingsratio 5 procentpunten lager is, of anders gezegd: dat voor dezelfde pensioenrechten een jaar langer moet worden doorgewerkt dan in regime I. De gebruikte vervangingspercentages in dit experiment zijn realistisch te noemen. Huynen en Fouarge (2005) laten op basis van administratieve gegevens van het CBS zien dat het gemiddelde bruto vervangingspercentage van mannen die in 1999 op leeftijden tussen 
55 en 65 zijn uitgetreden ongeveer $86 \%$ bedroeg (wat overeen zou komen met een netto-netto vervangingsratio van ongeveer $89 \%$ ). Bovendien was het vervangingspercentage van mannen die op 63-jarige leeftijd stopten vrijwel 100\%. Deze percentages hebben betrekking op de door de betreffende personen gekozen uittredeleeftijd, deels onder overgangsregelingen van VUT naar prepensioen. Daarom zijn in ons keuze-experiment lagere vervangingspercentages gekozen en hebben de leeftijdprofielen een steiler verloop dan de vervangingsratio's bij de in 1999 feitelijk gekozen pensioenleeftijden. ${ }^{5}$

Bij deze gestileerde uittredingsbeslissing kan de respondent uitsluitend kiezen op welke leeftijd hij of zij volledig stopt met werken. Als alternatief voor een dergelijk soort 'uittreding ineens' kan het voor werkenden aantrekkelijk zijn om gefaseerd uit te treden. Bijvoorbeeld door de omvang van de werkweek geleidelijk terug te brengen. In de enquête is daarom bovenstaand keuze-experiment herhaald voor een vergelijkbare keuze met deeltijduittreding. Hierbij is aan elke respondent gevraagd op welke leeftijd hij of zij zou uittreden als die uittreding gefaseerd zou plaatsvinden: eerst gedurende twee jaar een halvering van de werkweek en daarna volledig stoppen. De mogelijkheden waaruit de respondenten konden kiezen, zijn geënt op de opties in het regime dat hen was voorgelegd in de vraagstelling over volledige uittreding. Dit is gedaan door in plaats van volledig te stoppen bij de aangegeven leeftijd in tabel 2 een jaar eerder het aantal gewerkte uren te halveren en vervolgens na twee jaar volledig te stoppen met werken. Dus: als iemand op 60-jarige leeftijd de werkweek halveert en op 62-jarige leeftijd volledig stopt, geeft dat dezelfde pensioenrechten als wanneer in het oorspronkelijke experiment op 61-jarige leeftijd direct volledig was gestopt. De vragen over gefaseerde uittreding zijn uitsluitend gesteld aan respondenten met een baan van 24 uur per week of meer. Ook bij dit keuzeprobleem is eerst gevraagd op welke leeftijd iemand zou stoppen onder de gegeven keuzemogelijkheden. Dit onderdeel van het experiment is uitsluitend voorgelegd aan werkenden met een baan van 24 uur per week of meer.

\section{Uittreding als nutsmaximalisatie-probleem}

Figuur 1 geeft schematisch weer hoe de keuze in het experiment als nutsmaximalisatieprobleem kan worden voorgesteld. Elk punt in het vlak staat voor een combinatie van uittredeleeftijd $L$ en pensioenhoogte $P$. Aangenomen dat mensen meer vrije tijd (vroegere pensionering) hoger waarderen dan minder vrije tijd en dat voor geld (en dus de pensioenhoogte) hetzelfde geldt, vinden mensen combinaties beter naarmate zij meer naar links en/of naar boven liggen. De indifferentiecurves - de gekromde lijnen in figuur 1 - verbinden combinaties van $L$ en $P$ die een persoon even goed vind. De rechte lijnen zijn de regimelijnen en die geven aan welke combinaties van pensioenhoogte $P$ en uittredeleeftijd $L$ onder het geldende pensioenregime mogelijk zijn. Hoe steiler de regimelijn, hoe meer iemand aan pensioenrechten op moet geven om eerder te kunnen uittreden. Bij de onderbroken regimelijn in figuur 1 zal een nutsmaximaliserende werknemer kiezen voor de combinatie $\left(P_{0}, L_{0}\right)$, ofwel het punt waarin de regimelijn raakt aan de hoogst haalbare indifferentiecurve. In figuur 1 is het zuivere substitutie-effect weergegeven. Dit treedt op als de regimelijn zodanig verschuift dat deze bij een andere, in dit geval steilere, helling aan dezelfde indifferentielijn blijft raken. De uitkeringssystematiek is nu zodanig veranderd dat vroeger uittreden duurder is geworden in termen van opgegeven pensioenrechten, maar dat de persoon uiteindelijk niet beter of slechter af is, door een 'flankerende' verticale verschuiving van de lijn. Bij 
een dergelijke verschuiving van de regimelijn zal de nutsmaximaliserende werknemer ervoor kiezen om op latere leeftijd uit te treden $\left(L_{1}\right)$. Vervroegd uittreden wordt relatief duurder ten opzichte van consumptie en dus vervangt de werknemer in zijn optimale keuze vroegere uittreding door meer koopkracht $\left(P_{1}\right)$. Een verticale verschuiving omlaag van de regimelijn correspondeert met een algehele verlaging van de pensioenrechten, ongeacht de leeftijd waarop wordt uitgetreden. Dit is een zuiver inkomenseffect aangezien de prijs van vervroegd uittreden hetzelfde blijft. Als iemand er in koopkracht op achteruit gaat, zal hij van alle niet-inferieure goederen minder 'kopen', in dit geval dus minder vrije tijd, resulterend in latere uittreding, maar ook zal in het nieuwe optimum het pensioen lager zijn.

\section{Figuur I Substitutie-effect bij steiler profiel van het vervangingspercentage}

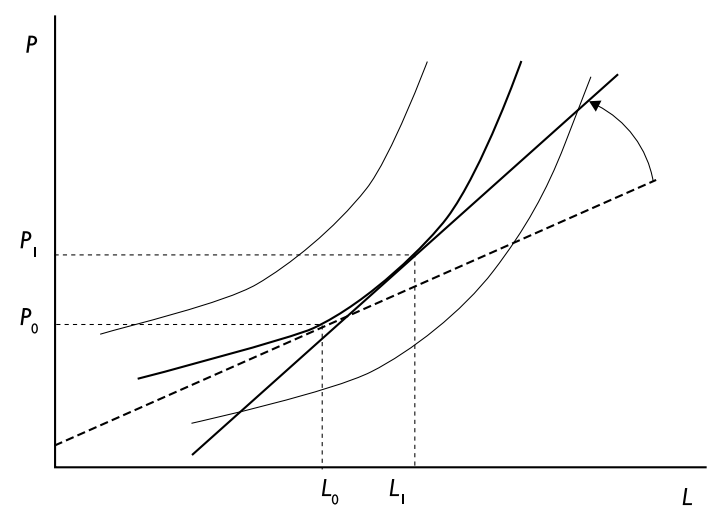

Met de verschillende regimes in het keuze-experiment variëren wij het substitutie- en het inkomenseffect van mogelijke aanpassingen. Van een substitutie-effect is sprake als de relatieve kosten en baten van de keuzemogelijkheden worden veranderd, maar met een impliciete compensatie die ervoor zorgt dat het pakket als geheel even aantrekkelijk blijft. Theoretisch kan dat door te zorgen dat de beste keuze voor de ingreep evenveel nut geeft als de beste keuze na de ingreep, zoals in figuur 1 . De compensatie verschilt dan van persoon tot persoon. Hier kiezen we er daarom voor de compensatie zo vorm te geven dat de pensioenrechten bij een bepaalde spilleeftijd gelijk blijven, en dus bij latere uittreding hoger worden en bij vroegere uittreding lager. Voor het ontwerpen van de pensioenregimes in tabel 2 is als spil de leeftijd van 66 jaar gekozen. De stap van regime I naar regime II heeft in die zin het karakter van een substitutie-effect, terwijl de stap van regime I naar regime III overeenkomt met een inkomenseffect.

Het is goed om te benadrukken dat iedere respondent maar één van de drie regimes kreeg voorgelegd. Verschillen tussen de keuzes die de respondenten onder de verschillende regimes hebben gemaakt, zijn dus niet ontstaan door onderlinge vergelijking van de regimes door de respondenten, maar geven de verschillen tussen de keuzes van respondenten die alleen het aan hun voorgelegde regime kennen. 


\section{Resultaten}

\section{Gekozen uittredeleeftijden}

Figuur 2 toont voor elk van de drie regimes de verdeling van de leeftijden waarop de respondenten zouden willen uittreden. Bij regime I is 62-jarige leeftijd favoriet, gevolgd door 60 en 65. Opvallend is dat de verdeling meerdere toppen heeft (multimodaal) en dat 61 als uittredeleeftijd aanmerkelijk minder populair is dan 60 of 62 . Dat bepaalde leeftijden in de perceptie van mensen beter als uittredeleeftijd passen dan andere is ook zichtbaar in feitelijk uittredegedrag, al kan de institutionele vormgeving van uitkeringsregelingen dit tot op zekere hoogte verklaren. Ten opzichte van regime I kiezen de respondenten binnen regime II voor hogere uittredeleeftijden. Weliswaar is 62 ook hier het populairst, maar we zien geen concentratie meer bij 60 en 63 neemt nu de tweede plaats in. Bij regime III zien we een totaal andere verdeling, met 64 en 66 als minst populaire leeftijden. Dat is waarschijnlijk het gevolg van de 'klank' van 65 als leeftijd om met pensioen te gaan. Voor het overige is het een veel gladdere verdeling dan bij de eerste twee regimes.

Figuur 2 Gekozen uittredeleeftijden voor elk regime

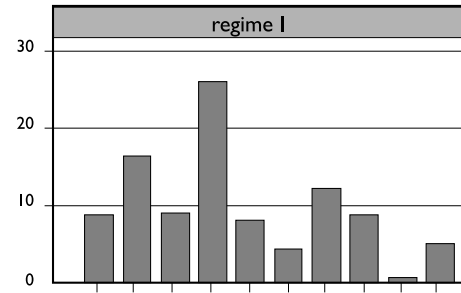

$\begin{array}{llllllllll}59 & 60 & 61 & 62 & 63 & 64 & 65 & 66 & 67 & 68\end{array}$

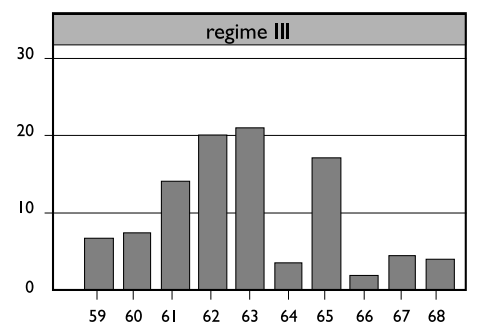

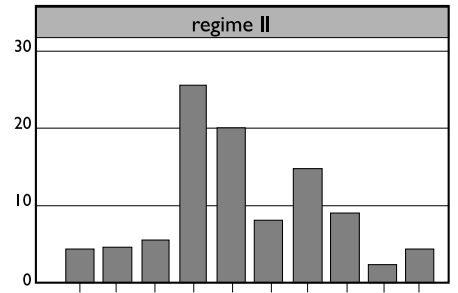

$\begin{array}{llllllllll}59 & 60 & 61 & 62 & 63 & 64 & 65 & 66 & 67 & 68\end{array}$

De verschillen tussen de gemiddelde uittredeleeftijden bij elk van de drie regimes zijn statistisch significant en bij minder genereuze mogelijkheden voor vervroegde uittreding blijken mensen langer door te werken. Onder regime II werken mensen gemiddeld achtenhalve maand langer door dan onder regime I. Tussen regimes I en III is het verschil iets kleiner: gemiddeld werken de mensen bij regime III drieënhalve maand langer door dan bij regime I.

\section{Schattingen van model voor volledige uittreding}

Het keuzeprobleem in de vignettenopzet behelst een keuze tussen een aantal discrete opties en is vergelijkbaar met een keuze tussen verschillende pakketten goederen. Voor de analyse van dergelijke keuzes wordt doorgaans gebruik gemaakt van het random- 
utility-model, verwant aan het (conditioneel) multinomiaal logistisch model (zie bijvoorbeeld Louvière et al. (2000) in de context van vignettenonderzoek). De pakketten waartussen een keuze moet worden gemaakt, bestaan in dit geval uit de bij een bepaalde uittredeleeftijd behorende hoeveelheid vrije tijd en de hoogte van de bijbehorende pensioenuitkering volgens de geldende regeling. Doordat het bij dit keuzeprobleem om in de tijd geordende keuzemogelijkheden gaat, kan met het ordinaal logistisch model (Maddala, 1983) een spaarzamere modelspecificatie worden gebruikt. ${ }^{6}$ Dit model analyseert hoe de kans waarmee een respondent voor één van de keuzemogelijkheden zal kiezen, afhangt van de kenmerken van die persoon zelf en de kenmerken van de betreffende optie. In het model wordt het gezamenlijke effect van de waargenomen kenmerken uitgedrukt in een latente index, waarvan een hogere waarde samenhangt met een gemiddeld hogere uittredeleeftijd.

Zoals in de vorige paragraaf is besproken, zijn in de vragenlijst drie verschillende pensioenregimes gebruikt, die elk met behulp van een toevalsgenerator aan een derde deel van de steekproef zijn toegewezen. In de analyses moeten daarom naast persoonlijke kenmerken ook de relevante kenmerken van het uittredingsregime worden meegenomen. In tabel 2 is goed te zien dat de regimes zich onderscheiden door de helling en de verticale positie van de leeftijdprofielen die het netto vervangingspercentage van pensioenuitkering ten opzichte van eerder arbeidsinkomen relateren aan de uittredeleeftijd. Daarom worden de drie regimes in de analyses gekarakteriseerd door de helling - de stapgrootte waarmee de pensioenrechten dalen bij een jaar vroegere uittreding en de leeftijd waarop bij uittreding het pensioen netto gelijk is aan het daarvoor verdiende inkomen. Elk van beide zal de uittredingskeuze beïnvloeden, maar op een verschillende wijze, vergelijkbaar met het substitutie- en het inkomenseffect van prijsveranderingen.

Met uitzondering van de regimekenmerken - de leeftijd waarbij de vervangingsratio $100 \%$ is en de stapgrootte waarmee de vervangingsratio per jaar eerdere uittreding afneemt - en factorscores voor de attitude t.a.v. werk en pensionering, zijn de variabelen in categorieën gecodeerd en als dummy-variabelen in het model opgenomen. Uit de enquête is een aantal kenmerken bekend voor het tijdstip van de enquête zelf en voor een aantal veranderlijke kenmerken is in de enquête expliciet gevraagd naar wat de respondent verwacht dat die op 59-jarige leeftijd zullen zijn. Dit is bijvoorbeeld gebeurd voor de omvang van de werkweek en de aanwezigheid van een werkende partner. ${ }^{7}$ In de modelspecificatie worden alleen kenmerken gebruikt die betrekkelijk constant zijn over de tijd of die expliciet voor de situatie op 59-jarige leeftijd zijn gevraagd. Naast variabelen als geslacht, geboortecohort en opleiding is in de analyse ook een aantal attitude-indicatoren opgenomen. Daarvoor is aan de respondenten een aantal stellingen voorgelegd over werk en uittreding. In totaal betrof het 34 items die door middel van vijf bloksgewijze factoranalyses zijn teruggebracht tot elf schalen. ${ }^{8}$ Drie schalen hebben betrekking op de oriëntatie van de respondenten op de toekomst en pensionering, deze belichten respectievelijk financiële, meer algemene aspecten en de rol van de partner daarin. De vierde factor representeert het belang van betaalde arbeid in het leven. Twee verdere factoren belichten de rol van eigen verantwoordelijkheid en solidariteit bij het betaalbaar houden van oudedagsvoorzieningen. De overige vijf factoren weerspiegelen de overwegingen die bij de uittredebeslissing een rol kunnen spelen: (1) de aantrekkelijke aspecten van het werk, (2) gezondheid en tijdautonomie, (3) meer tijd hebben voor familie, vrienden, hobby's en vrijwilligerswerk, (4) meer tijd voor partner, kinderen en kleinkinderen en (5) de financiële consequenties van pensionering. 
Elk van de elf factoren is gestandaardiseerd en een hogere waarde geeft aan dat het betreffende aspect sterker van toepassing is. Tabel 3 geeft een overzicht van de schattingsresultaten.

Tabel 3 Parameterschattingen van het ordinaal logistisch model van de geprefereerde uittredeleeftijd bij volledige uittreding $(N=I .22 I)$

\begin{tabular}{|c|c|}
\hline & Parameterschat \\
\hline \multicolumn{2}{|l|}{ Pensioenregime } \\
\hline leeftijd waarop vervangingspercentage $100 \%$ is & $0,388^{* *}$ \\
\hline stapgrootte & $0,360 * *$ \\
\hline Vrouw & 0,062 \\
\hline \multicolumn{2}{|l|}{ Geboortecohort (ref: <=1940) } \\
\hline $1941 \mathrm{t} / \mathrm{m} 1950$ & $-0,398 * *$ \\
\hline $1951 \mathrm{t} / \mathrm{m} 1965$ & $-0,687 * *$ \\
\hline 1966 of later & $-0,385^{*}$ \\
\hline \multicolumn{2}{|l|}{ Opleiding (ref: lo/vmbo) } \\
\hline $\mathrm{mbo} / \mathrm{havo} / \mathrm{vwo}$ & 0,224 \\
\hline hbo/wo & 0,042 \\
\hline \multicolumn{2}{|l|}{ Baantevredenheid (ref: laag) } \\
\hline midden & 0,161 \\
\hline hoog & 0,263 \\
\hline \multicolumn{2}{|l|}{ Sociale klasse (ref: (zeer) laag) } \\
\hline gemiddeld & 0,167 \\
\hline hoog & 0,004 \\
\hline zeer hoog & 0,294 \\
\hline Heeft een partner & $-0,|7|$ \\
\hline Heeft een werkende partner & 0,000 \\
\hline \multicolumn{2}{|l|}{ Lengte werkweek (ref: 20 uur of minder) } \\
\hline $21 \mathrm{t} / \mathrm{m} 32$ uur & $0,578 * *$ \\
\hline 33 uur en meer & $1,005^{* *}$ \\
\hline \multicolumn{2}{|c|}{ Tevredenheid met inkomen (ref: kan (zeer) moeilijk rondkomen) } \\
\hline niet moeilijk of gemakkelijk & $-0,337 * *$ \\
\hline (zeer) gemakkelijk & $-0,825 * *$ \\
\hline \multicolumn{2}{|l|}{ Oriëntatie op toekomst en pensioen } \\
\hline op financiële aspecten & $-0,087$ \\
\hline algemeen & $-0,|7| * *$ \\
\hline betrokkenheid partner bij beslissing & $-0,145 * *$ \\
\hline Centraliteit werk in het leven & 0,043 \\
\hline \multicolumn{2}{|l|}{ Mening over oudedagsvoorzieningen } \\
\hline eigen verantwoordelijkheid & $0,115^{\text {** }}$ \\
\hline solidariteit naar draagkracht & 0,073 \\
\hline \multicolumn{2}{|l|}{ Overwegingen bij uittredingsbeslissing } \\
\hline werk & $0,316^{* *}$ \\
\hline gezondheid & $-0,3 \mid 4 * *$ \\
\hline familie, hobby's e.d. & $-0,194 * *$ \\
\hline partner, (klein)kinderen & 0,000 \\
\hline financieel & $0,359 * *$ \\
\hline
\end{tabular}

Additionele controles: constante termen bij de modellen (drempelwaardes): 60, 6I, 62, 63, 64, 65, 66, 67 en 68 jaar

$*=$ significant op $10 \%$; ** = significant op $5 \%$ 
De kernvariabelen in deze analyse, de regimekenmerken, hebben beide een sterk significant effect. Versobering van de uittredingsregeling, hetzij door een algehele verlaging van de vervangingsratio van pensioen ten opzichte van eerder arbeidsinkomen, hetzij door een hogere 'boete' op vervroegde uittreding, leidt ertoe dat mensen langer doorwerken. De geschatte coëfficiënten impliceren dat een verandering van regime I naar regime II de uittredeleeftijd met negen maanden verhoogt en een verandering van regime I naar regime III tot gemiddeld vijf maanden latere uittreding leidt. Dit komt goed overeen met de resultaten van Bruinshoofd en Grob (2006). ${ }^{9}$ Op basis van de geschatte coëfficiënten kan ook voor andere aanpassingen van het pensioenregime worden nagegaan hoe zij de gemiddelde uittredeleeftijd beïnvloeden, bijvoorbeeld door vanuit regime I de stapgrootte van 5 naar $7 \%$ te verhogen en daarnaast de leeftijd waarop het netto pensioen gelijk is aan het netto inkomen te verhogen van 66 naar 67 jaar. Door deze combinatie van ingrepen zal de uittredeleeftijd gemiddeld met één jaar en drie maanden stijgen (tabel 4).

Figuur 3 laat zien hoe volgens deze schattingen de kansverdeling van de uittredeleeftijd door de vormgeving van het pensioenregime wordt beïnvloed. De figuur laat zien dat het percentage werknemers dat op 62-jarige leeftijd nog werkt onder regime I $42 \%$ zou bedragen, onder regime III 50\% en onder regime II 57\%. Bij hogere of lagere uittredeleeftijden is de afstand tussen de drie lijnen minder groot.

Figuur 3 Cumulatieve kansverdeling van de uittredingsleeftijd onder de drie verschillende pensioenregimes

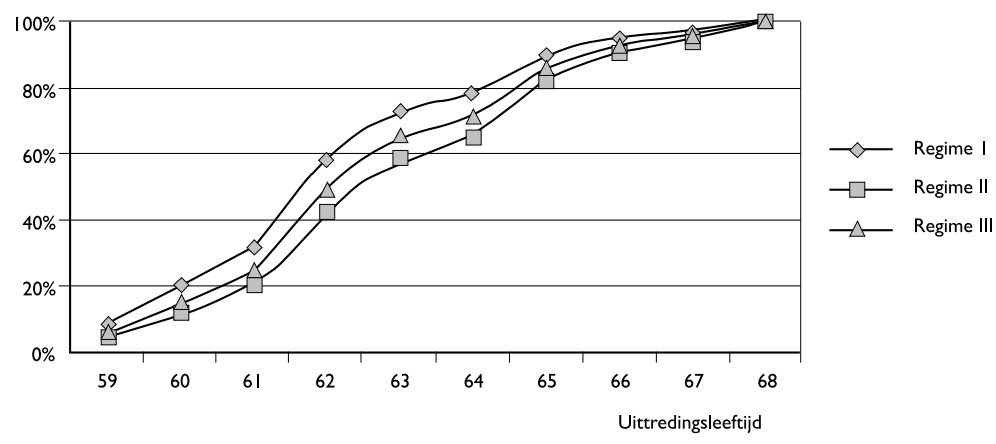

Tabel 4 Voorspeld effect van pensioenregime op de gemiddelde uittredeleeftijd

\begin{tabular}{|c|c|c|}
\hline \multirow[t]{2}{*}{$\begin{array}{l}\text { Leeftijd waarop netto-netto } \\
\text { vervanging } 100 \% \text { bedraagt }\end{array}$} & \multicolumn{2}{|c|}{$\begin{array}{l}\begin{array}{l}\text { Vermindering netto-netto vervangingsratio per jaar eerder } \\
\text { stoppen }\end{array}\end{array}$} \\
\hline & $5 \%$ & $7 \%$ \\
\hline 66 & 62 jaar +6 maanden & 63 jaar +3 maanden \\
\hline 67 & 62 jaar +11 maanden & 63 jaar +9 maanden \\
\hline
\end{tabular}

\section{Achtergrondkenmerken}

Naast deze financiële prikkels zijn ook andere factoren van invloed op de keuze van de uittredeleeftijd. Latere geboortecohorten willen gemiddeld eerder stoppen met werken dan het oudste cohort in de data (geboren voor 1941). Dit laatste cohort was ten tijde van de enquête 65 jaar of ouder en is gevraagd terug te denken aan de laatste baan voor hun zestigste verjaardag en vanuit die situatie een keuze te maken. Hun 
keuzes wijken sterk af van die van de jongere respondenten. Tussen de jongere cohorten zijn de verschillen kleiner, al is bij het middelste cohort (geboren tussen 1951 en 1965) de wens om vroeg uit te treden het sterkst.

Opvallend is dat, na correctie voor de andere opgenomen kenmerken, er geen systematisch verschil tussen mannen en vrouwen is. Baantevredenheid is in beperktere modelspecificaties van belang, maar het opnemen van attitude-indicatoren neemt de verklaringskracht hiervan weg. Het is dus niet de baantevredenheid zelf die ertoe doet, maar eerder de wijze waarop mensen tegen hun pensionering aankijken. De wens om vervroegd uit te treden is het sterkst bij mensen met een voltijdbaan. Van de mensen met een deeltijdaanstelling willen vooral degenen met een kleine deeltijdbaan (twintig uur per week of minder) het langst doorwerken.

De economische welstand is in het model opgenomen met indicatoren voor de sociale klasse, opleiding en indicatoren voor het gemak waarmee men zegt te kunnen rondkomen van het huishoudinkomen. Opleiding blijkt in alle gebruikte specificaties niet of nauwelijks van belang, evenmin als de sociale klasse. Wel blijkt dat mensen die gemakkelijk of zeer gemakkelijk kunnen rondkomen van hun inkomen gemiddeld vroeger met werken te willen stoppen.

Van de drie factorscores voor de oriëntatie op toekomst en pensioen blijken er twee van invloed. Opvallend genoeg blijkt de score die betrekking heeft op financiële zaken - de indicator die aangeeft of mensen zich goed hebben geïnformeerd en bezig zijn met sparen voor na hun pensionering - nauwelijks van invloed. Wel wijst het teken van de coëfficiënt eerder op vroegere dan latere uittreding van mensen die zich sterker op de financiële aspecten van pensionering hebben georiënteerd. Een sterker effect geeft de algemene toekomstoriëntatie, die aangeeft of mensen niet 'van dag tot dag' leven en het leuk vinden om na te denken over hoe zij in de toekomst zullen leven. Een sterkere toekomstoriëntatie hangt samen met vroegere uittreding. Ook mensen die een partner hebben en daarmee gezamenlijk over pensionering overleggen, blijken vaker vervroegd te willen uittreden. Of mensen bij maatregelen om de AOW betaalbaar te houden eerder van solidariteit dan van eigen verantwoordelijkheid uitgaan, maakt voor de eigen uittredeleeftijd geen verschil.

Hoewel de aan werk gerelateerde overwegingen om door te werken naar eigen zeggen niet echt bepalend lijken voor de keuze van de uittredeleeftijd, blijken mensen die werk van belang vinden - sociale contacten via het werk, het werk geeft aanzien, is leuk of geeft het gevoel maatschappelijk nuttig te zijn - wel degelijk gemiddeld langer door te willen werken, evenals mensen die aangeven dat financiële overwegingen van belang zijn bij de keuze van de uittredeleeftijd. Daar staat tegenover dat mensen die aangeven dat gezondheid een belangrijke overweging zou zijn, of die het belangrijk vinden meer tijd voor familie en vrienden, hobby's of vrijwilligerswerk te hebben, eerder willen uittreden dan gemiddeld. Opvallend is dat mensen die te kennen geven dat meer tijd hebben voor partner, kinderen en kleinkinderen een belangrijke overweging is bij de uittredingsbeslissing de facto niet vroeger of later uittreden dan de mensen die deze overweging niet van belang vinden. 


\section{Gefaseerde uittreding}

Blank et al. (2004) beargumenteren dat de benodigde groei van de arbeidsparticipatie - of in ieder geval wat beleidsmakers als doelstelling daarvoor hanteren - ruimschoots bereikt kan worden door een systeem van deeltijdpensionering in te voeren. Belangrijk voordeel van een dergelijk systeem is dat het door verlichting van de werklast kan bevorderen dat mensen gezond de eindstreep halen en voorkomen wordt dat het terugdringen van vervroegde uittreding leidt tot een grotere instroom in WAO en WW. Bovendien is denkbaar dat gefaseerde uittreding beter aansluit bij individuele voorkeuren van werknemers. De vraag is dus: zal een dergelijk uittredingssysteem in een behoefte voorzien bij de mensen die in de komende jaren voor de keuze staan te stoppen of door te gaan met werken.

Op de uitkomsten van deze variant van het keuze-experiment gaan wij hier slechts kort in, aangezien veel resultaten overeenkomen met die voor directe uittreding. Ook bij gefaseerde uittreding zien we dat bij regime II minder vaak voor de vroegste uittredingsmogelijkheden wordt gekozen. De gemiddelde uittredeleeftijd ligt minder dan een jaar boven de overeenkomstige leeftijd in het geval van directe uittreding. Bij regime II is het verschil met acht maanden het kleinst. Kennelijk verschuift bij de keuze tussen gefaseerde uittredingsopties de voorkeur licht in de richting van korter werken. Zoals gezegd zijn de vragen over gefaseerde uittreding alleen gesteld aan mensen die minstens 24 uur per week werkten. In de vorige paragraaf bleek dat deze groep langer wil doorwerken dan de mensen met kortere banen. Dat maakt het gevonden verschil tussen de gemiddelde uittredeleeftijd bij directe uittreding en bij gefaseerde uittreding nog saillanter.

Opnieuw kan de gemaakte keuze worden geanalyseerd met een ordinaal logistisch model. Omdat alleen mensen met een baan van minstens 24 uur per week deze vragen hebben beantwoord, is de steekproef voor deze analyses kleiner: 689 in plaats van 1221 respondenten. De kernvariabelen in deze analyse, de regimekenmerken, hebben evenals bij de analyses van volledige uittreding beide een sterk significant effect. Wel is het effect van de stapgrootte kleiner dan bij directe uittreding. De geschatte coëfficiënten impliceren een verschil in gemiddelde uittredeleeftijd van zeven maanden tussen regime I en regime II. Dit is kleiner dan het verschil van negen maanden dat we bij directe uittreding vonden. Het verschil in gemiddelde uittredeleeftijd tussen regime I en regime III is met zes maanden iets hoger dan het verschil bij directe uittreding. Zoals tabel 5 laat zien, zou een combinatie van beide aanpassingen leiden tot dertien maanden latere uittreding, bij de vergelijkbare opties voor directe uittreding bedroeg dat effect vijftien maanden.

Tabel 5 Voorspeld effect van pensioenregime op de gemiddelde uittredeleeftijd bij gefaseerde uittreding

\begin{tabular}{ccc}
\hline $\begin{array}{c}\text { Leeftijd waarop netto-netto } \\
\text { vervanging 100\% bedraagt }\end{array}$ & \multicolumn{2}{c}{ Vermindering netto-netto vervangingsratio per jaar eerder } \\
stoppen
\end{tabular}

De uittredeleeftijd is de leeftijd waarop definitief met werken wordt gestopt nadat twee jaar eerder de werkweekomvang al met de helft is teruggebracht. 
Blijft staan dat versobering van de uittredingsregeling, in de vorm van een algehele verlaging van de vervangingsratio van pensioen ten opzichte van eerder arbeidsinkomen of in de vorm van een hogere 'boete' op vervroegde uittreding, ertoe leidt dat mensen langer doorwerken. Figuur 4 geeft voor elk van de drie regimes het verloop van de cumulatieve kansverdeling van de uittredeleeftijd weer. Net als bij onmiddellijke volledige uittreding ligt het percentage dat op een gegeven leeftijd niet meer werkt bij regime I hoger dan bij beide andere regimes, maar het verschil tussen regimes II en III is bij gefaseerde uittreding klein, voornamelijk doordat bij gefaseerde uittreding het vergroten van de stapgrootte een kleiner effect heeft dan bij onmiddellijke uittreding.

Figuur 4 Cumulatieve kansverdeling van de uittredingsleeftijd onder de drie verschillende pensioenregimes voor gefaseerde uittreding

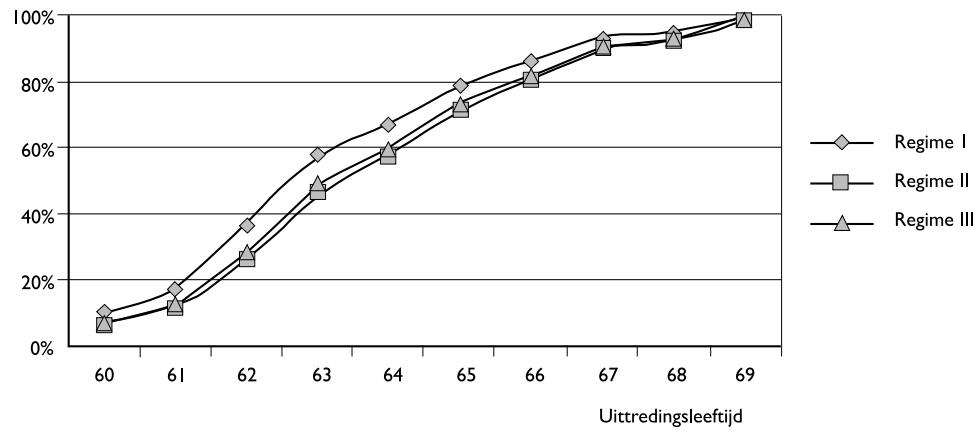

De uittredeleeftijd is de leeftijd waarop definitief met werken wordt gestopt nadat twee jaar eerder

de werkweekomvang al met de helft is teruggebracht.

\section{Conclusies en beleidsimplicaties}

Door middel van een experimentele opzet wordt in dit artikel onderzocht wat het effect is van financiële prikkels op de keuze van de leeftijd waarop mensen uit het arbeidsproces terugtreden. De voor dit onderzoek gebruikte vignettenmethode maakt het mogelijk om preciezer te controleren voor de omstandigheden waaronder mensen moeten kiezen. Het hier gebruikte experiment is eenvoudig en overzichtelijk: het heeft veel weg van een regulier pensioenoverzicht waarin gevraagd wordt een uittrede leeftijd met een daarbij behorend vervangingsinkomen te kiezen. Bovendien is de keuze relevant voor alle deelnemers aan het experiment.

In de experimentele opzet is een drietal uittredingsregimes bekeken, waarbij vanuit het eerste regime door dit op twee verschillende manieren te versoberen de beide andere ontstaan. De eerste versobering is door vanuit een zelfde uittredeleeftijd die recht geeft op een pensioen ter hoogte van het eerdere inkomen, elk jaar dat iemand eerder uittreedt zwaarder te beboeten. En, wat op hetzelfde neerkomt, ieder jaar dat iemand langer doorwerkt sterker te belonen. Dit steilere profiel maakt vrije tijd duurder en bijgevolg doorwerken aantrekkelijker. Het moet daarom tot minder vroege uittreding leiden. Hierbij is sprake van een zogenaamd substitutie-effect: vervroegd uittreden wordt duurder en dus 'koop' je daar minder van. De tweede manier om de vervroegdeuittredingsregeling te versoberen, is door de pensioenrechten bij elke leeftijd te verlagen. Het effect hiervan op de uittredingsbeslissing is te zien als een inkomenseffect: minder 
koopkracht wordt vertaald in een lagere consumptie van 'normale' goederen: je kunt je de luxe van vervroegd uittreden minder veroorloven en werkt daarom langer door.

De resultaten in dit onderzoek laten zien dat beide vormen van versobering leiden tot latere uittreding. Dit effect is het grootst als de pensioenrechten sterker dalen bij vroegere uittreding (substitutie-effect). Maar ook een algehele verlaging van de pensioenrechten leidt tot latere uittreding (inkomenseffect). Deze effecten worden zowel gevonden bij de keuze tussen verschillende mogelijkheden om direct uit te treden, d.w.z. zonder voorafgaande werktijdreductie, als bij de keuze tussen verschillende mogelijkheden gefaseerd uit te treden, d.w.z. door eerst de werkweek met de helft terug te brengen gedurende een periode van twee jaar en pas daarna volledig te stoppen. Echter, bij directe uittreding heeft een verandering in de prijs van vrije tijd een groter effect op de uittredeleeftijd dan een algehele verlaging van de pensioenrechten. Bij gefaseerde uittreding hebben beide ingrepen een vergelijkbaar effect. Dit komt waarschijnlijk doordat bij gefaseerde uittreding een jaar langer doorwerken uitgesmeerd is over twee jaren waarin in nog maar voor de helft wordt doorgewerkt. Deze vormgeving is uiteraard van invloed op de relatieve waarde van vrije tijd.

Het onderzoek in dit artikel laat duidelijk zien dat financiële prikkels van invloed zijn op de uittredingsbeslissing, ook al speelt daarnaast nog een aantal andere individuele factoren een rol die mede de voorkeuren voor uittreding bepalen. Beleidsmatig geven de bevindingen aan dat versobering van uittredingsarrangementen leidt tot latere uittreding op de arbeidsmarkt. Financiële prikkels die vroegtijdige uittreding willen ontmoedigen, blijken invloed te hebben. Versobering van het uittredingsregime zal effect sorteren. De mate waarin en wijze waarop dit beleidsinstrument zal worden ingezet, is uiteraard uiteindelijk een politieke keuze en een politieke beslissing.

\section{Noten}

1 Het recentelijk verschenen advies van de Commissie Arbeidsparticipatie (2008) besteedt specifiek aandacht aan de mogelijkheden om de arbeidsdeelname van ouderen te vergroten. Zie verder Van den Brink en Heemskerk (2006) voor een zeer lezenswaardig overzicht van het huidige debat over de vergrijzing in wetenschap en beleid.

2 Kerkhofs, Lindeboom en Theeuwes (1999) bespreken het effect van gezondheid op uittreding. Jettinghoff en Smulders (2008) laten zien dat werkkenmerken en de fysieke belasting van werk bepalend zijn. Henkens (1998) gaat in op de bepalende rol die werkgevers soms spelen als het om uittreding gaat. Hurd (1990) bespreekt de rol die partners spelen in elkaars keuze om al dan niet uit te treden.

3 Zie voor meer informatie over het CentER-panel: www.uvt.nl/centerdata.

4 Wij gebruiken netto vervangingspercentage zodat het voor de respondent duidelijk is wat het effect van zijn/haar keuze is op zijn/haar koopkracht. Merk op dat netto vervangingspercentages hoger uitvallen dan vervangingspercentages berekend op het brutoloon.

5 De gebruikte vervangingspercentages zijn hoger dan degene die gebruikt zijn door van Soest et al. (2006) bij een vergelijkbare vignettenonderzoek. Zoals gezegd zijn de door ons gebruikte percentages gebaseerd op volledige pensioenopbouw en het uitgangspunt dat iemand die tot op 66- of 67-jarige leeftijd doorwerkt er bij pensionering netto niet op achteruitgaat.

6 Het ordinaal logistisch model is te vergelijken met een gewoon logistisch model, maar met meerdere oplopende uitkomsten.

7 Van de respondenten van 60 of ouder is teruggevraagd naar de situatie van de laatste baan voor hun zestigste verjaardag. Andere aan werk gerelateerde kenmerken (sector van activiteit, arbeidsomstandigheden, e.d.) en gezondheid worden in de schattingen niet meegenomen omdat verwacht mag worden dat deze in de loopbaan nog zullen veranderen. 
8 Per blok zijn de geconstrueerde factoren onderling onafhankelijk en is de toewijzing van items aan de factoren door middel van varimax-rotatie zo onderscheidend mogelijk gemaakt. De factoren zijn gestandaardiseerd (gemiddelde 0 en variantie 1). Zie Kerkhofs et al. (2007) voor een gedetailleerde beschrijving van de gebruikte variabelen en voor een vollediger overzicht van de schattingsresultaten.

9 Bruinshoofd en Grob (2006) concluderen dat het verhogen van de standaard pensioenleeftijd met één jaar leidt tot gemiddeld vijf à zes maanden latere uittreding. Bij dat onderzoek is eveneens gebruik gemaakt van gegevens uit een vignettenonderzoek, maar de respondenten kregen daarbij achtereenvolgens zes verschillende uitkeringssystemen voorgelegd. Ons keuze-experiment verschilt daarvan in de zin dat elke respondent slechts één willekeurig toegewezen uittredingsregeling kreeg voorgelegd, waardoor deze niet zelf de alternatieve pensioensystemen kon vergelijken.

\section{Literatuur}

Blank, J., Hulst, B. van \& Selm, A. van (2004). Pensioen én participatie. Economisch Statistische Berichten, 89, 198-200.

Brink, D. van den \& Heemskerk, F. (2006). De vergrijzing leeft; kansen en keuzen in een verouderende samenleving. Amsterdam: Uitgeverij Bert Bakker.

Bruinshoofd, W.A. \& Grob, S.G. (2006). Do changes in pension incentives affect retirement? A stated preference approach to Dutch retirement considerations. DNB Working Paper No. 115. Amsterdam: De Nederlandsche Bank.

Carson, R., Flores, N., Martin, K. \& Wright, J. (1996). Contingent valuation and revealed preference methodologies: comparing the estimates for quasi-public goods. Land Economics, 72 , 80-99.

Commissie Arbeidsparticipatie (2008). Naar een toekomst die werkt. Rotterdam: Commissie Arbeidsparticipatie.

Dalen, H. van \& Henkens, K. (2000). Hoe prikkelbaar is de oudere werknemer? ESB 24-03-2004, 243-245.

Euwals, R., Vuuren, D. van \& Wolthoff, R. (2005). Early retirement behaviour in the Netherlands. Evidence from a policy reform. CPB Discussion Paper No. 52. The Hague: CPB.

Ewijk, C. van, Draper, D.A.G., Rele, H.J.M. ter \& Westerhout, E.W.M.T. (2006). Ageing and the sustainability of Dutch public finances. Bijzondere publicatie 61. Den Haag: Centraal Planbureau.

Henkens, K. (1998). Older workers in transition: studies on the early retirement decision in the $\mathrm{Ne}$ therlands. NIDI Rapport 53. Den Haag: NIDI.

Hurd, M.D. (1990). Research on the elderly: economic status, retirement and consumption and saving. Journal of Economic Literature, 28, 565-637.

Huynen, B. \& Fouarge, D. (2005). Inkomenseffecten van uittreding. Sociaal-Economische Trends, 1ste kwartaal 2005, 49-56.

Jettinghoff, K. \& Smulders, P. (2008). Wie kan en wil er doorwerken tot 65-jarige leeftijd? Tijdschrift voor Arbeidsvraagstukken, 24, 88-100.

Kapteyn, A. \& de Vos, K. (1999). Social Security and Retirement in the Netherlands. In J. Gruber \& D.A. Wise (red.), Social security and retirement around the world. Chicago: The University of Chicago Press.

Kerkhofs, M., Fouarge, D. \& Ester, P. (2007). Financiële prikkels en voorkeuren bij uittreding: resultaten uit een experimenteel onderzoek. OSA-publicatie A223. Tilburg: OSA.

Kerkhofs, M., Lindeboom, M. \& Theeuwes, J. (1999). Retirement, financial incentives and health. Labour Economics, 6(2), 203-228.

Lazear, E.P. (1986). Retirement from the labour force. In O. Ashenfelter \& R. Layard (red.), Handbook of labor economics (vol. 2, pp. 305-355). Amsterdam: North-Holland.

Lindeboom, M. (1999). Het arbeidsmarktgedrag van oudere werknemers. Oratie. Vrije Universiteit Amsterdam.

Louvière, J.J., Hensher, D.A. \& Swait, J.D. (2000). Stated choice methods; analysis and applications. Cambridge: Cambridge University Press.

Maddala, G.S. (1983). Limited-dependent and qualitative variables in econometrics. Cambridge: Cambridge University Press.

Nelissen, J.H.M. (2001). Het effect van wijzigingen in vervroegde uittredingsregelingen op de arbeidsparticipatie van oudere werknemers. Tilburg: CentER-Applied Research. 
Schils, T. (2005). Early retirement patterns in Europe; a comparative panel study. Amsterdam: Dutch University Press.

Soede, A. \& Bijkerk, W. (2003). De VUT voorbij? Pensioen en ouderenparticipatie. Breukelen: Nyfer. Soest, A. van, Kapteyn, A. \& Zissimopoulos, J. (2006). Using stated preferences data to analyze preferences for full and partial retirement. DNB Working Paper No. 81. Amsterdam: De Nederlandsche Bank. 